\title{
A STUDY OF PREVALENCE OF SACRALIZATION OF L5 VERTEBRA
}

\section{Anjali Sabnis ${ }^{1}$, Manisha Nakhate ${ }^{* 2}$.}

${ }^{1}$ Professor and head, Department of Anatomy, MGM Medical College, Kamothe, Navi Mumbai, Maharashtra, India.

*2 Professor and head, Department of Anatomy, D. Y. Patil Medical College, Nerul, Navi Mumbai, Maharashtra, India.

\section{ABSTRACT}

Sacrum is centrally located unpaired bone of pelvis which is composed of 5 sacral vertebrae. Superiorly it articulates with $5^{\text {th }}$ lumbar vertebra to form lumbosacral joint and laterally it articulates with hip bone to form sacroiliac joint. When $5^{\text {th }}$ lumbar vertebra fuses with $1^{\text {st }}$ sacral vertebra then it is called as sacralization and when $1^{\text {st }}$ sacral vertebra gets separated from sacrum then it is called as lumbarization. 79sacra from the department of Anatomy of MGM medical college and D. Y. Patil medical college, Navi Mumbai were studied to see sacralization. Out of 79 sacra in 14 sacra(17.7 \%) sacralization was observed.Out of 14 sacra, 4 sacra showed bilateral and complete sacralization, 5 sacra showed unilateral and partial sacralization and 5 sacra showedincomplete fusion between L5 and S1 vertebra. Change in normal structure of lumbar vertebra and sacrum may lead to alteration in kinematics of lumbosacral region which may lead to compression of nerve and low back pain. Knowledge regarding incidence of sacralization will be useful for radiologist and orthopaedic surgeon while dealing with low back pain.

KEY WORDS: Sacrum, Lumbar Vertebra, Sacralization, Lumbosacral Region.

Corresponding Author: Dr. Manisha Nakhate, Professor and head, Department of Anatomy, D. Y. Patil Medical College, Nerul, Navi Mumbai, Maharashtra, India.

E-Mail: manishanakhate@yahoo.com

Access this Article online

Quick Response code

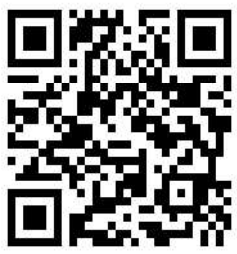

DOI: $10.16965 /$ ijar.2020.112

Journal Information

International Journal of Anatomy and Research

RG Journal ISSN (E) 2321-4287 | ISSN (P) 2321-8967

https://www.ijmhr.org/ijar.htm

DOI-Prefix: https://dx.doi.org/10.16965/ijar

Article Information

Received: 29 Jan 2020

Peer Review: 30 Jan 2020

Revised: None
Accepted: 20 Feb 2020

Published (O): 05 Mar 2020

Published (P): 05 Mar 2020

\section{INTRODUCTION}

Sacrum is large, triangular, unpaired bone which is wedged between two hip bones and forms posterior wall of pelvis. 5 sacral vertebrae fuse with each other in such a way that sacrum has concavity anteriorly and convexity posteriorly forming pelvic and dorsal surface respectively. Superior surface of sacrum articulates with inferior surface of body of $5^{\text {th }}$ lumbar vertebra to form symphysis type of joint and forms lumbosacral angle. The lumbosacral angle is the angle formed between the long axis of the lumbar vertebrae and the sacrum [1]. It is sometimes defined as the angle formed between the superior surface of the sacrum and the horizontal [2]. The weight borne by the cervical and thoracic vertebrae is transmitted to the lumbosacral spine to sacrum and then to the femur through ilium. The lumbosacral joint also permits flexion, extension and rotation movements [3]. It is thus subject to subluxation and frequent injuries and therefore important in assessment of back pain [4].

When five sacral and $5^{\text {th }}$ lumbar vertebrae fuse then the condition is called as sacralization.The transverse process of $5^{\text {th }}$ lumbar vertebra fuses with sacrum or ilium. This anomaly is observed in about $3.6 \%$ to $18 \%$ of people and is usually 
bilateral ${ }^{5}$. This condition occurs due to defect in the segmentation of the lumbosacral spine during development [5].

In sacralization the structure of lumbar and sacral vertebra changes which lead to change in lumbosacral angle. Sacralisation of L5 leads to more stress concentration on L4-L5 motion segment, which may result in further degenerative changes in the facet joint, disc degeneration and anterior slippage of L4 on L5 [6,7]. L5 sacralization is also considered to be a predisposing factor for degenerative spondylolisthesis at L4-L5 $[8,9]$.

This leads to change in bio-mechanics and becomes responsible for low back pain. While dealing with low back pain incidence of sacralization should be kept in mind so that errors in spine surgery can be nil and can reach to highest excellent outcome. This study aims to study the incidence of sacralisation of lumbar vertebra in dry sacrum.

\section{MATERIALS AND METHODS}

79 dry sacra of unknown age and sex were collected from the department of Anatomy of MGM medical college and D. Y. Patil medical college, Navi Mumbai. Sacralization was observed in terms of unilateral, bilateral, complete and partial.

\section{RESULT AND OBSERVATIONS}

Fig. 1: Shows complete bilateralsacralization in 4 sacra.

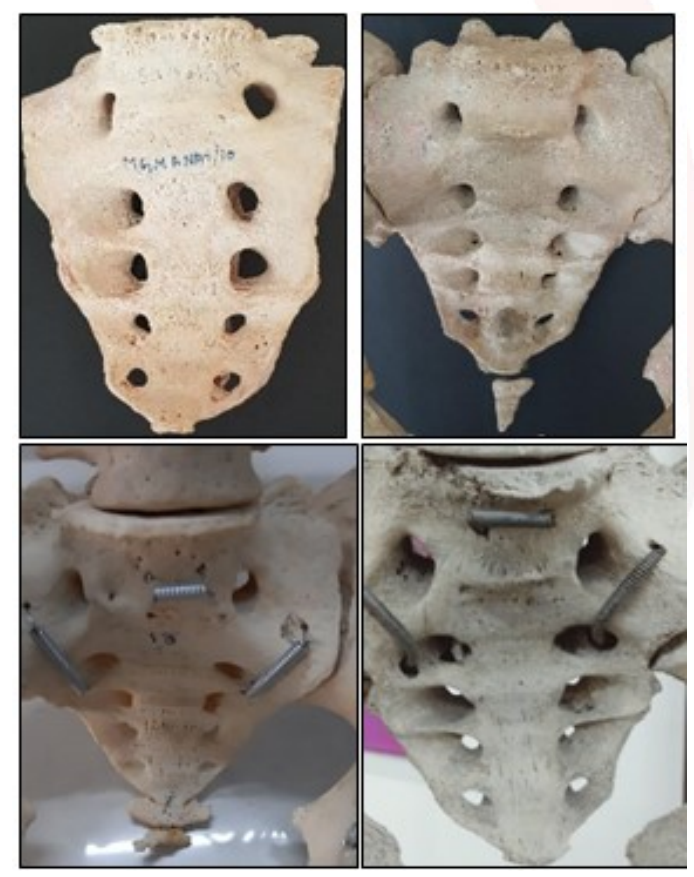

Fig. 2: Shows unilateral partial sacralization in 5 sacra.
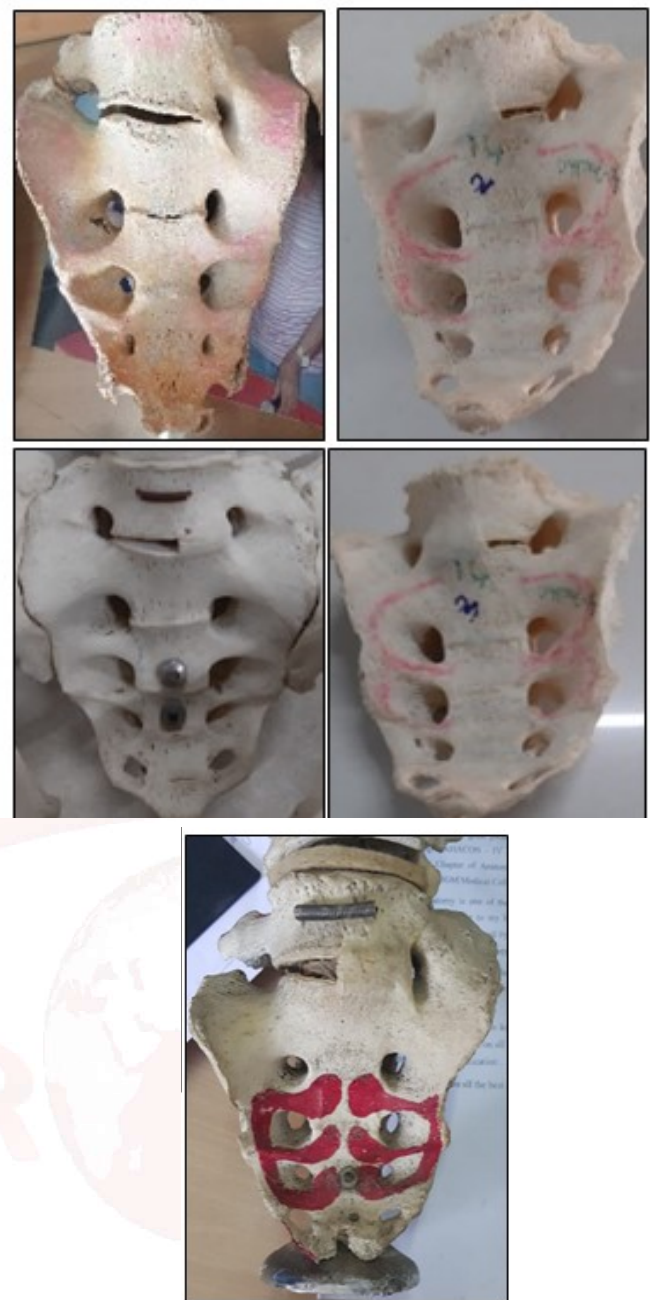

Fig. 3: Showsincomplete fusion between L5 and S1 vertebra in 5 sacra.
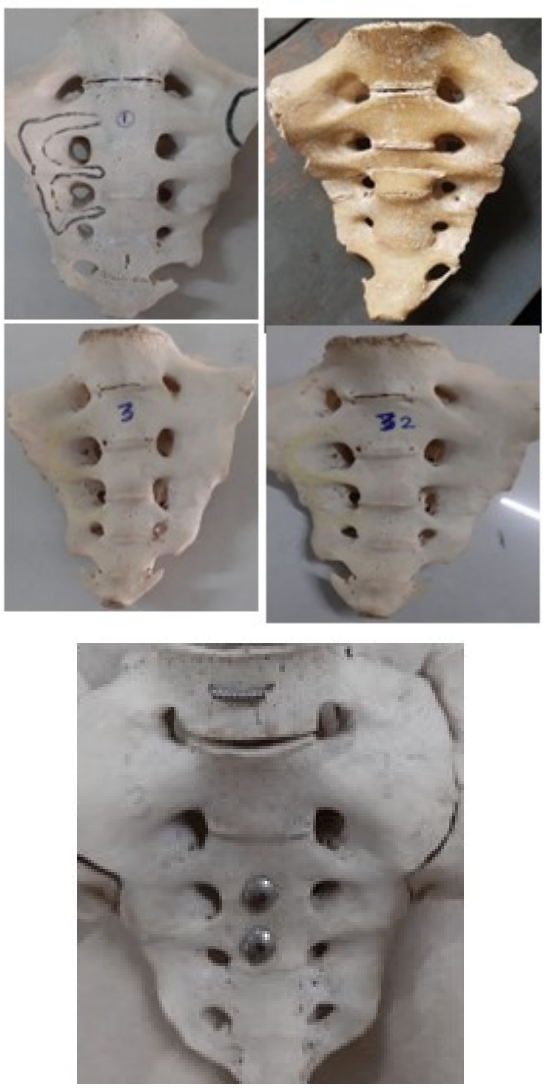
It was found that

1. Out of 79 sacra, in 14 sacra, sacralization was observed

2. Out of 14 sacra, 4 sacra showed bilateral and complete sacralization (Fig. 1)

3. Out of 14 sacra, 5 sacra showed unilateral and partial sacralization (Fig. 2)

4. Out of 14 sacra, 5 sacra showed incomplete fusion between L5 and S1 vertebra in 5 sacra (Fig. 3)

\section{DISCUSSION}

Lumbosacral region is lowermost part of vertebral column which is complex and composed of five lumbar vertebrae and sacrum. Sacralization and lumbarisation are normal anatomical variants at the L5-S1 vertebral level [10]. Sacralization of the L5 vertebrae is characterized by broadened elongated transverse processes to complete fusion to the sacrum [11.12].

"Sacralization of L5" was said to occur when the transverse process of the last lumbar vertebra formed either a bony bridge or a pseudarthrosis with the sacral ala [13]. In the majority of cases, transition is incomplete or unilateral ${ }^{13}$. The incidence of sacralisation of the fifth lumbar vertebra is $11.1 \%$ [5], $10 \%, 16 \%[15,16], 9.2 \%$ [17], 6.2\% [18], 8.1\% [19], 3.6\% [20] while in the present study it is higher $17.7 \%$.

Sacralization is linked to embryology of lumbosacral vertebrae. Development of lumbar vertebra commences at $3^{\text {rd }}$ week of intrauterine life. All vertebrae originate from somites that form along the cranial-caudal axis, on either side of the notochord, from pre-somatic mesoderm. These somites differentiate further into sclerotome \& dermomyotome. Each sclerotome consists of loosely packed cells cranially and densely packed cells caudally. Some densely packed cells move cranially apposite the centre of myotome where they form intervertebral disc and remaining densely packed cells fuse with the loosely arranged cells of immediately caudal sclerotome to form mesenchymal centrum, body of vertebra. The mesenchymal cells surrounding the neural tube form neural arch. Ossification of vertebra begins in $8^{\text {th }}$ week $\&$ completed by $25^{\text {th }}$ year. Two primary centres
$\&$ five secondary centres (one centre for tip of spinous process, each transverse process \& two each for annular epiphyses) are present for each vertebra [21]. These processes are considered to be regulated by the respective homeobox and paired-box genes, Pax 1 and Pax 9 in the control of cell proliferation during early sclerotome development. As revealed in mice that were deficient for one functional copy of Pax 1 , heterozygosity and homozygosity of the Pax 9 mutation result in vertebral malformations in the lumbar region, such as fused and split vertebrae, as well as ossified fusions between vertebrae and neural arches. Thus, the cartilage between L5 and S1 vertebrae calcified to become a" sacralisation" of the fifth lumbar vertebra, may be caused by some genetic determinants of these morphological changes from the somite to vertebrae. This hypothesis was supported by a previous study of Tini (1977) [22] as increased incidences of lumbosacral transitional vertebrae were observed occurring within families.

Sacralisation is a congenital anomaly which may lead to change in makeup of lumbosacral region in terms of lumbosacral angle and biomechanics. It may lead to compression of nerve, pressure on soft tissue and stretching of ligaments in the vicinity of sacralisation. It contributes to the development of degenerative spondylolisthesis lumbar disc degeneration and herniation, and low back pain [8-10,12,23-25]. Sacralisation in females causes difficulty in labour due to less mobile pelvis because of fusion of lumbosacral joint. It may be reason for low back ache [5]. Some authors have stated that sacralization is incidentally diagnosed and has no clinical impact $[26,27]$, whereas others claim that this anomaly may predispose patients to certain clinical disorders [9-28]. There was a definite causal relationship between the transitional vertebra and degeneration of the disc immediately cephalad to it [8.13].

As low back pain is associated with lumbosacral region, surgical interventions are commonly occurring in this region. Errors in numeric identification of the vertebrae have been reported to cause spinal surgery at incorrect levels on numerous occasions, and the incidence of this is undoubtedly higher in patients with sacralisation $[25,29]$. Few spine surgeons 
always prefer to study plain lumbar $\mathrm{X}$ ray prior to the surgery though the MRI is done.

\section{CONCLUSION}

Awareness of sacralization and its incidence and application of such knowledge during and prior surgery will definitely reduce procedural errors to reach to the best outcome.

\section{Conflicts of Interests: None}

\section{REFERENCES}

[1]. Ferguson AB clinical and roentgen interpretation of lumbosacral spine. Radiology. 1934;22:548-558.

[2]. Meshan I. Farra- Meshan RM.(ed) Atlas of Normal Radiographic Anatomy 2nd edition. Saunders Company Philadelphia.1985:416-419.

[3]. Cecil Maduforoetal, Study of the Lumbosacral Angles of Males in Port Harcourt, South- South, Nigeria, The Nigerian Health Journal 2012;12(1).

[4]. Abitbol MM. Evolution of the lumbosacral angle. Am J Phys Anthropol. 1987; 72:361-372.

[5]. KubavatDharatietal, A study of sacralisation of fifth lumbar vertebra in Gujarat, National Journal Of Medical Research, 2012;2(2):211-213.

[6]. Lee CK, Langrana NA. Lumbosacral spinal fusion. A biomechanical study. Spine. 1984;9:574-581.

[7]. Hambly MF, Wiltse LL, Raghavan N, Schneiderman G, Koenig C. The transition zone above a lumbosacral fusion. Spine. 1998;23:1785-1792.

[8]. Elster AD. Bertolotti's syndrome revisited. Transitional vertebrae of the lumbar spine. Spine. 1989;14:1373-1377.

[9]. Magora A, Schwartz A. Relation between the low back pain syndrome and $x$-ray findings.Transitional vertebra (mainly sacralization) Scand J Rehabil Med.1978;10:135-145.

[10]. Wigh R E. The thoracolumbar and lumbosacral transitional junctions. Spine (Phila $\mathrm{Pa}$ 1976) 1980;5(3):215-222.

[11]. Konin G P, Walz D M. Lumbosacral transitional vertebrae: classification, imaging findings, and clinical relevance. AJNR Am J Neuroradiol. 2010;31(10):1778-1786.

[12]. Castellvi A E, Goldstein L A, Chan D P. Lumbosacral transitional vertebrae and their relationship with lumbar extradural defects. Spine (Phila Pa 1976) 1984;9(5):493-495.

13]. Vijay Sekharappa,etal, Lumbosacral Transition Vertebra: Prevalence and Its Significance, Asian spine journal, 2014, 8(1),51-58.

[14]. Bron J L, van Royen B J, Wuisman P I. The clinical significance of lumbosacral transitional anomalies. Acta Orthop Belg. 2007;73(6):687-695.
[15]. Bustami F. The anatomical features and functional significance of lumbar transitional vertebra. Jordan Med J 1989;23:49-59.

[16]. Shobha kumaretal, Study of sacralisation of fifth lumbar vertebra, journal of dental and medical sciences, 2016;15(11):58-61.

[17]. Vandana A.Sharma,D. K.Sharma, C.K.Shukla. Osteogenic study of lumbosacral transitional vertebra in central India region.J.Anat.Soc.India 2011;60(2): 212-217.

[18]. Peter H, Wilm B, sakai N, Imai K, Maas R, Balling R. Pax 1 and Pax 9 synnergistically regulate vertebral column development. Development 1999;126:5399408.

[19]. Brailsford JF. Deformities of the lumbosacral region of the spine. Brit J Surg 1928; 16: 562-627.

[20]. Moore BH, Illinois C. Sacralization of the fifth lumbar vertebra. J Bone Joint Surg 1925;7:271-278.

[21].Keith. L. Moore,T.V.N.Persaud, The Developing human,clinically oriented embryology Skeletal system.8th edition, published by Saunders, Elsevier,Philadelphia, 2008:344-346.

[22]. Tini PG, WISes G, Ainn WM. The transitional vertebrae of the lumbrosacral spine: Its radiological classification, incidence, prevelence, and clinical significance. RheumatolRehabi 1977;16:180-5.

[23]. Berlemann U, Jeszenszky DJ, Buhler DW, Harms J:The role of lumbar lordosis, vertebral end-plate inclination, disc height, and facet orientation in degenerative spondylolisthesis. J Spinal Disord 1999; 12: 68-73.09.

[24].Otani K, Konno S, Kikuchi S: Lumbosacral transitionalvertebrae and nerve-root symptoms. J Bone Joint Surg Br2001; 83: 1137-1140.

[25].Wigh RE, Anthony HF Jr: Transitional lumbosacraldiscs. Probability of herniation. Spine 1981;6:168-171.

[26]. M. W. van Tulder, W. J. J. Assendelft, B. W. Koes, and L. M. Bouter. Spinal radiographic findings and nonspecific low back pain: a systematic review of observational studies. Spine 1997;22(4):427-434.

[27]. H. Paajanen, M. Erkintalo, T. Kuusela, S. Dahlstrom, and M. Kormano. Magnetic resonance study of disc degeneration in younglow-backpainpatients,Spine, 1989;14(9):982-985.

[28]. H. S. Chang and H. Nakagawa, "Altered function of lumbar nerver ootsin patients with transition allumbosacralvertebrae. Spine 2004;29(15):16321634.

[29]. Konin G P, Walz D M. Lumbosacral transitional vertebrae: classification, imaging findings, and clinical relevance. AJNR Am J Neuro-radiol. 2010;31(10):1778-1786. 